\title{
A DESCONSTRUÇÃO DO SAGRADO: A IMAGEM DE DEUS NO ROMANCE $O$ EVANGELHO SEGUNDO JESUS CRISTO, DE JOSÉ SARAMAGO
}

Diogo Duarte Prado ${ }^{1}$

RESUMO: Trabalho com o objetivo de refletir acerca da desconstrução do sagrado feita em $O$ evangelho segundo Jesus Cristo, de José Saramago, observando-se como os valores do divino, como a própria imagem de Deus, são retratados na narrativa. Refletir-se-á sobre o envolvimento das personagens José e Jesus para com a vontade do sagrado, percebendo-se o preço e desgaste que idolatrar esse Deus causa. Como base teórica para a análise, usar-se-á dos pensamentos de Arthur Schopenhauer, Friedrich Nietzsche, Sigmund Freud, dentre outros, com a finalidade de demonstrar o processo de desconstrução da suposta "superioridade e perfeição" dos céus, por parte do romance saramaguiano.

PALAVRAS-CHAVE: Sagrado. Desconstrução. Deus. Literatura Portuguesa. José Saramago

Em O evangelho segundo Jesus Cristo (1991), do escritor português José Saramago (1922-2010), apresenta-se uma perspectiva acerca daquilo que é, culturalmente falando, conhecido como sagrado, abordando-se sobre as figuras de Jesus, José e Deus de um modo crítico, repensando e desconstruindo a ideia do divino. Na narrativa, Saramago desenvolve as características de suas personagens, salientando aquilo que tais possuem de realmente humano ou, em determinados momentos, apontando aspectos negativos no que seria sagrado e, logo, "perfeito". Sua história tem como principal enfoque as personagens do carpinteiro José e de Jesus, trilhando um caminho de humanidade, no qual são realçados seus defeitos que os tornam verdadeiramente comuns e mortais.

No início do livro, o narrador deixa claro que a história comentada é de cunho ficcional, ou seja, não se tratando de uma verdade: "[...] o que temos diante de nós é papel e tinta" (SARAMAGO, 1991, p. 11). Desenvolvendo a sua fala, o narrador comenta brevemente sobre Jesus, apontando que este será o único dentre os crucificados que terá grandes honras, o seu nome perpetuando ao longo dos tempos, divinizado.

Entretanto, mostra-se claro, já nas primeiras páginas do romance, que a ideia de sagrado não é propriamente vinculada a algo bom, isento de erros e de fatores negativos, pois o narrador saramaguiano expõe a seguinte perspectiva de que "o Bem e o Mal não existem em si mesmos, cada um deles é somente a ausência do outro" (SARAMAGO, 1991, p. 16).

1 Mestre em Letras pela Universidade Federal do Rio Grande, FURG, Brasil. Email: diogoduartep@hotmail.com

Revista de Letras JUÇARA, Caxias - Maranhão, v. 02, n. 01, p. 84 - 101, jul. 2018 | 84 
A obra possui, pode-se dizer, duas partes: uma tendo como protagonistas José e Maria, e a outra se centrando na vida de Jesus. A primeira demonstra as duas personagens como indivíduos simples, um casal que arca com as obrigações da vida, trabalhando e sendo temente a Deus. A partir desse momento, começam as críticas quanto ao pensamento do sagrado. Discorrendose quanto a ambos como marido e mulher, destaca-se a importância do masculino e do feminino, por serem capazes de gerar vida.

Devido a tal raciocínio, o narrador diz que estes são a fonte e a taça da vida, forças capazes de gerar outro ser, uma questão a qual, mesmo na sua grandiosidade, "o próprio Deus não entende, embora as tivesse criado" (SARAMAGO, 1991, p. 25), esses questionamentos se baseiam em uma falta de entendimento que possui o ser sagrado.

Mostra-se que, em meio a sua suposta sabedoria, essa figura de Deus é sujeita a erros, a princípios que se fariam presentes unicamente no homem. $\mathrm{O}$ sagrado está próximo e é demasiado similar ao que é definido como mundano. Quando um suposto anjo surge à porta de Maria, ele se apresenta não como um ser superior, mas trajando vestes de mendigo e pedindo comida. Tal sujeito afirma que Maria está grávida, mas o efeito causado não é o de um aviso que vem dos céus, mas o de um estranhamento por parte da mulher que enxerga, naquele ser, somente um mendigo. Há uma desconfiança, uma incerteza que se faz sentir, mesmo quando José profere que "todo o poder está no Senhor Deus, ele é o que sabe [...] Deus quis o que fez e fez o que quis, é nas suas mãos que está o meu filho, eu nada posso" (SARAMAGO, 1991, p. 62).

Por mais que José se ponha como inferior a tal ser sagrado, paira uma desconfiança quanto aos julgamentos e a sabedoria deste Deus, principalmente quando se trata de seus julgamentos e da segurança que tal pode prover ao seu filho que está por vir. Em diálogo com um de seus vizinhos, José expressou a ideia de superioridade desse sagrado². Porém, ao observar a pobreza e a chacina que o cerca, tornava-se árduo acreditar na benevolência e no discernimento dos céus.

\footnotetext{
2 José afirma que a sua vida, como a de sua esposa e a do filho que virá, encontram-se protegidas e guiadas por Deus. Contudo, os conflitos que o cercam, soldados batalhando entre si, colocamno em um estado de alerta.
} 
A personagem começava a adentrar em um pensamento que questionava o quão bondoso e superior realmente viria a ser este Deus, pois o mundo que tal poder divino havia criado era envolto por caos. Conversando com um ancião chamado Simeão, José escuta as seguintes palavras: "[...] cada um de nós é este pouco e este muito, esta bondade e esta maldade, esta paz e esta guerra, revolta e mansidão" (SARAMAGO, 1991, p. 62-63).

A aproximação feita entre o bem e o mal, o sagrado e o profano, o divino e o mortal se mostra ainda mais expressiva no momento em que o narrador descreve o nascimento de Jesus, personagem a qual no consenso geral é vista como um ser sagrado e superior: "O filho de José e de Maria nasceu como todos os filhos dos homens, sujo do sangue de sua mãe, viscoso das suas mucosidades e sofrendo em silêncio. Chorou porque o fizeram chorar, e chorará por esse mesmo e único motivo" (SARAMAGO, 1991, p. 81).

Desse modo, nota-se como este sagrado não é tão distinto daquilo visto como natural. A onipotência e perfeição do divino na verdade são superficiais, a partir do momento em que tanto uma suposta representação do divino vem ao mundo como um homem comum. Igualmente, repensa-se quanto à soberania deste Deus, que se comenta tudo poder, mas que, ironicamente, em meio ao cenário de precariedade que existe no vilarejo de José e Maria "não podia prover a tudo" (SARAMAGO, 1991, p. 88). ${ }^{3}$

Através de tal raciocínio, pode-se usufruir dos pensamentos propostos pelo filósofo alemão Arthur Schopenhauer (1788-1860). A sua filosofia, vista como pessimista, vê a vida de uma maneira negativa, baseada em desapontamentos e sofrimentos. O pensador, em seu livro As dores do mundo (1850), discorre que o mundo é um local em que impera a dor, no qual a impressão que passa é a de que se trata de um ambiente de contínua penitência, no qual o ser humano se encontra abandonado. Schopenhauer diz que no percurso do homem "a desgraça geral é a regra" (SCHOPENHAUER, 2014, p. 25) e define a realidade como "uma guerra sem tréguas" na qual "morre-se com as armas na mão" (SCHOPENHAUER, 2014, p. 26).

\footnotetext{
${ }^{3} \mathrm{Na}$ ficção de Saramago, aborda-se constantemente a incapacidade de Deus em resolver as dificuldades na terra. Como será visto no desenvolver do trabalho, a imagem desse ser é representada como desinteressado para com as situações vivenciadas pelo homem.
} 
O cenário apresentado pelo filósofo é de horror e barbárie, em que os homens estão estimulados a ferirem uns aos outros, inclinados a sofrerem e proliferarem a dor. Trata-se de possuírem aspectos hostis em si, a capacidade de serem "maus". Contudo, se há uma figura de demasiada capacidade que é Deus, um sagrado capaz de "purificar" a malignidade da existência, tais dores não deveriam ser a regra. O romance de Saramago explora a ideia de que o sagrado é, mais do que afetado, responsável pelas ações negativas e pela atmosfera conflituosa em meio aquela existência.

Assim, o sagrado é detentor de falhas, culpabilidades e submissões perante os sentimentos bestiais que deveriam envolver somente o humano. Tal representação daquilo que é divino, Deus, tem em si méritos e deméritos, como salienta o próprio narrador da ficção que, ao falar da criação dos anjos, observa: "[...] é verdade que quem fez uns anjos fez os outros, mas depois emendou a mão" (SARAMAGO, 1991, p. 125).

Provocativamente, a narrativa demonstra que tal sagrado contribui para as confusões que ocorrem na vida humana. Através de omissões, ou escolhas equivocadas, gera as dificuldades que se encontram ao redor de pessoas humildes e simples, como as personagens José e Maria. Do mesmo modo, devido à imperfeição deste divino, acontecem matanças e calamidades que enfatizam o pensamento schopenhaueriano de que "O mundo é o inferno, e os homens dividem-se em almas atormentadas e em diabos atormentadores" (SCHOPENHAUER, 2014, p. 28). ${ }^{4}$

Pela ausência de atitudes coerentes e benéficas, por parte dessa representação do sagrado, para com a humanidade, os indivíduos se sentem abandonados, sentindo a necessidade de agirem por si, como é deixado explícito no romance: "[...] quando se tornou patente que Deus não vem nem dá sinal de chegar tão cedo, o homem não tem mais remédio que fazer-lhe as vezes e sair de sua casa para ir pôr ordem no mundo ofendido, a casa que é dele e o mundo que a Deus pertence" (SARAMAGO, 1991, p. 137).

\footnotetext{
${ }^{4}$ A filosofia de Schopenhauer tem como ponto central a relação entre o homem e a dor, a dificuldade que há em existir nesse mundo. O pensador estabelece que existir é um fardo, sem possibilidades de melhora. A realidade seria somente a vivência de experiências de sofrimento, e sua única saída seria a morte. Pensando na obra literária, ver-se-á que o espaço em que se encontram as personagens possibilita pensar em tal ideia, já que sentimentos como o abandono e a solidão se fazem consideravelmente perceptíveis.
} 
Agindo por si mesmo, o homem percebe que está perdido, sem rumo. José e Maria notam que se encontram neste estado, por surgir a necessidade de se deslocarem, saírem de seu vilarejo devido aos conflitos que vem ocorrendo. Sem ajuda, devem percorrer outros caminhos pelo mundo, dependendo somente das próprias forças. Contudo, independentemente do local no qual estão residindo, em seu entorno há apenas sangue derramado.

Enquanto isso se passa, as personagens se perguntam como Deus pode permitir tais atrocidades, a morte de adultos e de crianças. O próprio Jesus, ainda jovem, faz, segundo uma conjectura do narrador, a seguinte pergunta a si mesmo, em pensamento: "Quando chegará, Senhor, o dia em que virás a nós para reconheceres os teus erros perante os homens" (SARAMAGO, 1991, p. 142).

Na narrativa do autor português, Deus comete erros, omite-se e pouco faz a favor dos cidadãos. A morte é a primeira imagem a qual os olhos das personagens alcançam, e isso se deve a apatia dessa figura sagrada que não intervém, deixando aqueles indivíduos sem a possibilidade de escaparem da violência. Schopenhauer afirma, em Aforismos para a sabedoria de vida (1851), que "quase todos os nossos sofrimentos têm origem na sociedade" (SCHOPENHAUER, 2014, p. 136), ou seja, o convívio junto ao próximo gera angústia e dor, fatores que surgem por causa desse pouco interesse do sagrado para com os mortais. Todavia, na ficção a culpa quanto aos erros, aos pecados, é em parte atribuída ao divino: "Deus não perdoa os pecados que manda cometer" (SARAMAGO, 1991, p. 159).

Percebe-se que a questão dos pecados, atribuída ao ser humano, é estimulada, em parte, por Deus. Tal consideração faz com que se pense que o posicionamento por parte do divino é de manipulação, ou mesmo de abuso de poder, pois um dos principais agentes do erro é este ser superior que pune. A personagem José acaba por sofrer o resultado das decisões divinas, pagando 0 preço de ser somente um homem, um "temente a Deus", com a morte. Uma morte aparentemente injusta, mas que, seguindo o raciocínio exposto na ficção, é uma ocorrência decidida e aceita pelo divino. ${ }^{5}$

\footnotetext{
${ }^{5}$ José acaba por ser confundido como soldado inimigo, resultando tal questão em uma morte de sofrimento na cruz. Em seus pensamentos, em meio ao desespero, somente consegue pensar que morrerá sem a menor culpabilidade: "Vou morrer, e vou morrer inocente" (SARAMAGO, 1991, p. 160), mas, partindo por um viés schopenhaueriano, é indiferente se há culpabilidade ou não,
} 
As situações representadas no romance passam a ideia de uma considerável apatia por parte do sagrado, uma ausência de influência positiva sobre a humanidade. Na obra literária, associa-se este fator que deveria ser superior com punição. Uma passagem que deixa evidente a desconstrução do sagrado, como algo bondoso, capaz de fazer surgir nas pessoas pensamentos e sentimentos positivos, dá-se pela seguinte consideração:

Fôssemos nós tão imprudentes, ou tão ousados, como as borboletas, falenas e outras mariposas, e ao fogo nos lançaríamos, nós todos, a espécie humana em peso, talvez uma combustão assim imensa, um tal clarão, atravessando as pálpebras cerradas de Deus, o despertasse do seu letárgico sono, demasiado tarde para conhecer-nos, é certo, porém a tempo de ver o princípio do nada, agora que tínhamos desaparecido. (SARAMAGO, 1991, p. 167)

Pensando-se nessa colocação, Deus passa um sentido de distanciamento, e mesmo de desinteresse, pelos acontecimentos mundanos. Enquanto os indivíduos sofrem, Deus apenas se preocupa em ser idolatrado, temido, visto como sagrado. Após a morte da personagem José, Maria se encontra na tarefa árdua de lidar com os filhos, abandonada pelo divino, arcando com uma sensação de solidão, de um vazio que deveria ser preenchido por esse sagrado, mas que apenas se torna mais significativo por causa dele.

Schopenhauer diz que "Se um Deus fez este mundo, eu não gostaria de ser esse Deus: a miséria do mundo esfacelar-me-ia o coração" (SCHOPENHAUER, 2014, p. 39), observar tal existência causa um desespero pelos incontáveis momentos de dor que se fazem sentir na relação do homem com o outro e consigo mesmo. Contudo, o pensamento do filósofo se aplicaria apenas a um Deus que se importasse, a um sagrado que se sensibilizasse pelas ocorrências na vida da terra. A imagem da divindade, no romance de Saramago, ignora a miséria do mundo.

Uma perspectiva teórica, que se aplica a essa representação do sagrado, é a explorada pelo alemão Friedrich Nietzsche (1844-1900). Crítico da religião, da metafísica e da moral, Nietzsche vê Deus como um mal da sociedade, uma ideia que limita o homem, salientando as suas fraquezas e o impedindo de ser livre,

pois o homem está destinado ao terror, ao fracasso e aos mais diversos tipos de dor. Dessa maneira, o que acontece com José é o resultado habitual da vida, de uma existência a qual está sob o domínio de um Deus que "está sempre pronto a sacrificá-los (os homens) sem piedade" (SCHOPENHAUER, 2014, p. 60). 
agir por si mesmo 6 . Questiona o sentido de bondade que vem atrelado a essa ideia do sagrado. Em seu livro Humano, demasiado humano (1878), Nietzsche diz:

\begin{abstract}
Como gostaríamos de trocar essas falsas afirmações dos sacerdotes, segundo as quais existe um Deus que de nós exige o bem, que é guardião e testemunha de toda ação, todo o momento, todo pensamento, que nos ama, que em toda desgraça deseja o melhor para nós - como gostaríamos de trocá-las por verdades que fossem tão salutares, calmantes e benfazejas como esses erros! (NIETZSCHE, 2005, p. 79)
\end{abstract}

Observa-se que, por parte de Nietzsche, há uma desconstrução desse sagrado, repensando tudo que fora dito através dos tempos sobre o divino, vendo-o como mentiras. Similarmente, é feito em $O$ evangelho segundo Jesus Cristo, Saramago apresenta a categoria do sagrado com tais características. Não somente humaniza, mas destaca sua incoerência e mesmo perversidade, estimuladas a partir de uma sensação de superioridade, ressaltada tanto por esse Deus como pelas próprias personagens, que se encontram "dominadas" pela vontade divina.

Desenvolvendo-se o romance, depois da morte de José, enfoca-se na personagem de Jesus Cristo. Envolvido por conflitos e dúvidas, após a perda de seu pai, Jesus pensa em sair de casa, ir trilhar o seu próprio caminho. Maria, desempenhando o papel materno, implora que Jesus, sendo o filho mais velho, permaneça no lar, exercendo a função de líder da família. Para sustentar seu argumento, Maria diz ser o correto, logo, a vontade de Deus. Estando em um estado emocional e psicológico envolto de incertezas quanto à sapiência divina, a personagem expressa os seguintes sentimentos para a mãe: "talvez os homens nasçam com a verdade dentro de si e só não a digam porque não acreditam que ela seja a verdade" (SARAMAGO, 1991, p. 191).

O posicionamento de Jesus significa, basicamente, que os homens possuem as respostas para as suas perguntas, não necessitando do auxílio do sagrado. Se existe o desejo de partir, se em seu interior isso lhe parece a medida correta, então o sujeito deve acatar a essa decisão, sem pedir a "permissão" de um Deus que impõe empecilhos e regras a seu bel prazer.

\footnotetext{
${ }^{6}$ Para Nietzsche, a ideia de Deus, como a religião, consolida o domínio sob o homem a partir da moral, por um conjunto de regras e proibições as quais, segundo o teórico, limitam o homem.
} 
Assim, Jesus decide por partir. Tenta trilhar o seu percurso, de um modo independente. Pode-se interpretar tal atitude como uma maneira de se opor a esse poder "opressor" que é o sagrado, o qual tenta impor "verdades", obrigando o sujeito a ir por um único caminho e adotar somente o pensamento cuja palavra de Deus considera inquestionável. Para Nietzsche, a proibição imposta por aquilo que é visto como sagrado "esmagou e despedaçou o homem por completo, e o mergulhou como num lodaçal profundo" (NIETZSCHE, 2005, p. 88). Pensando-se por esse viés, é perceptível na obra ficcional como o desejo por parte dessa figura superior é capaz de subjugar o sujeito, destroçando-o. Questão a qual se passou com José e que, de algum modo, a personagem Jesus tenta se sobressair. ${ }^{7}$

Desse modo, percorrendo o próprio caminho, Jesus acaba por encontrar o suposto anjo que, no passado, visitou a sua mãe. Este, adotando a identidade de um Pastor que conduz um rebanho de ovelhas, conversa com Jesus e tenta convencer, sutilmente, a personagem de segui-lo. Durante o diálogo, junto às primeiras impressões deixadas por aquele homem que se autodenomina como um anjo, Jesus cogita que tal ser não se trata de um anjo do senhor, principalmente pelos posicionamentos críticos que o indivíduo demonstrou possuir acerca do sagrado, questionando e mesmo refutando as leis e os valores impostos pelo Senhor. Debatendo com a personagem Pastor, Jesus se impressiona com o posicionamento de oposição advindo daquele homem, exclamando "Só o Senhor é Deus" (SARAMAGO, 1991, p. 231), na tentativa de refutar Pastor. Contudo, a discussão prossegue:

O sorriso de Pastor apagou-se, a boca ganhou de súbito um vinco amargo, Sim, se existe Deus terá de ser um único Senhor, mas era melhor que fossem dois, assim haveria um deus para o lobo e um deus para a ovelha, um para o que morre e outro para o que mata, um deus para o condenado, um Deus para o carrasco, Deus é uno, completo e indivisível, clamou Jesus, e quase chorava de piedosa indignação, ao que o outro respondeu, Não sei como pode Deus viver, a frase não passou daqui porque Jesus, com a autoridade de um mestre da sinagoga, cortou, Deus não vive, é, Nessas diferenças não sou entendido, mas o que te posso dizer é que não gostaria de me ver na pele de um deus que ao mesmo tempo guia a mão do punhal assassino e oferece a garganta que vai ser cortada, Ofendes a Deus com esses pensamentos ímpios, Não valho tanto, Deus não dorme, um dia te punirá, Ainda bem que não dorme, dessa maneira evita os pesadelos do

\footnotetext{
7 Atenta-se a questão de que as personagens se encontram, devido a esta ideia de Deus, aprisionadas a comportamentos e dogmas do sagrado. Tanto José quanto Jesus têm as suas vidas guiadas pelo divino, tornando-se, portanto, limitados.
} 
remorso, Por que me falas tu de pesadelos e remorso, Porque estamos a falar do teu deus, E o teu, quem é, Não tenho deus, sou como uma das minhas ovelhas, Ao menos dão filhos para os altares do Senhor, E eu digo-te que como lobos uivariam essas mães se o soubessem. Jesus ficou pálido, sem resposta. (SARAMAGO, 1991, p. 231)

Mesmo tentando provar que os métodos e ideais de Deus são a única possibilidade de verdade, o jovem Jesus se vê frente a uma perspectiva que o deixa envolto de dúvidas. Por mais que discorde, em um primeiro momento, de Pastor, Jesus sente uma inquietação em si. A palavra de Deus, ao mesmo tempo em que the parece absoluta, também the causa um desconforto.

Esse desconforto é um dos principais efeitos da desconstrução do sagrado por parte do livro de Saramago. Entorno da "perfeição" do divino, fazemse presentes aspectos que consomem personagens como José e Jesus em perguntas, as quais as possíveis respostas não são compatíveis com as suas convicções. Logo, impera a sensação de uma solidão, de um abandono, como já ressaltado, por parte desse ser sagrado e superior.

A exemplificação desse ponto é que, mesmo desconfiando de Pastor e, posteriormente, obtendo a certeza de que ele era um "anjo do inferno", Jesus continua a seu lado, exercendo o ofício junto ao rebanho. O ser humano necessita seguir alguém, precisa de uma base, um símbolo ou ser que o ajude a seguir com a sua vida. $O$ desprezo por parte do divino exige que as personagens do romance se apeguem ao que surgir a sua frente. Mostra-se que o sagrado, por vontade própria, é insuficiente para tal questão. O homem, é possível assim se interpretar, é incapaz de sobreviver aos desafios do mundo sozinho, precisa se apegar a algo que the traga uma sensação de proteção.

Em seu Psicologia das massas e análise do eu (1921), Sigmund Freud (1856-1939) expõe a ideia de que o sujeito, como o povo em geral, precisa ser liderado, ter uma "força", uma pessoa, ou mesmo uma simples motivação que o o inspire a agir. Devido a isso, o indivíduo "não conhece nem a dúvida nem a incerteza" (FREUD, 2013, p. 47), por ter a ciência de que algo superior o guia.

Contudo, na ficção não há uma figura que exerça tal função, pois, como no caso de Jesus, acaba-se optando por ficar próximo àquilo que, teoricamente, deveria repudiar, já que Pastor nega as vontades do sagrado. Sendo assim, é preciso notar que o lado simplesmente humano da personagem Jesus se 
expressa de maneira mais significativa do que sua devoção a Deus, por se mostrar evidente que este não age em prol da humanidade.

O Jesus Cristo de Saramago é muito mais homem do que um símbolo sagrado, por ceder às vontades mundanas. Ele se sente perdido, vulnerável, precisando de conselhos e ensinamentos, os quais Deus aparentemente não se importa em lhe passar. A personagem, por ser demasiado humana e, logo, demasiado imperfeita, segue um instinto de obediência, instigada pelos mais distintos sentimentos, como medo e inferioridade. Jesus se encontra como um aprendiz, o qual apenas possui segurança quando está com o seu mentor.

Torna-se possível pensar naquilo que Nietzsche define como "instinto de rebanho", a submissão frente aos valores do sagrado, da religião, na qual homens sem perspectiva se unem, para suportarem as suas fraquezas, como a solidão. Na obra Genealogia da moral, o filósofo desenvolve a sua perspectiva:

[...] a formação do rebanho é avanço e vitória essencial na luta contra a depressão. O crescimento da comunidade fortalece também no indivíduo um novo interesse, que com frequência bastante o eleva acima do elemento mais pessoal do seu desalento, sua aversão a si mesmo[...]. Todos os doentes, todos os doentios, buscam instintivamente organizarse em rebanho, na ânsia de livrar-se do surdo desprazer e do sentimento de fraqueza[...] onde há rebanho, é o instinto de fraqueza que o quis [...] (NIETZSCHE, 2009, p. 116)

O pensamento freudiano complementa essa ideia: "A massa é um rebanho obediente, que nunca pode viver sem senhor. Ela tem tal sede de obedecer que se subordina instintivamente a qualquer um que se nomeie seu senhor" (FREUD, 2013, p. 52). Assim, a humanidade se percebe em meio a um vazio, uma incompletude que a faz ser dependente de liderança, de ordens e de obediência. Esse sentimento pode ser visto na personagem Jesus, que prefere estar com Pastor, um ser opositor a Deus, do que sozinho. ${ }^{8}$

A interpretação que o romance possibilita é a de um sagrado que não serve como um alicerce para os devotos, da mesma maneira que Deus é inapto em governar o mundo, ou pelo menos despreza as situações do dia a dia dos

\footnotetext{
${ }^{8}$ Percebe-se que o Cristo de Saramago, podendo ser visto como a exemplificação do homem dependente de Deus, não é apto a galgar seus passos sozinho pelo mundo. Existe, em si, o sentimento de obediência, a submissão frente a outro. O sujeito é insuficiente para si mesmo, logo, segundo Freud, precisa de uma liderança, alguém que seja uma inspiração a qual "ama todos os indivíduos da massa com o mesmo amor. Tudo depende dessa ilusão" (FREUD, 2013, p. 74) Junto a essa ilusão, o sujeito sente possuir valor e importância.
} 
cidadãos. O divino é visto somente como algo vingativo, opressor, capacitado em desferir punições.

Em uma passagem da narrativa, Jesus, que se encontra em meio a uma tempestade, diz as seguintes palavras para o cordeiro que negou, em um primeiro momento, sacrificar a Deus: "Não tenhas medo, ele (Deus) só quis mostrar-te que te poderia ter morto, se quisesse, e a mim veio dizer-me que não fui eu quem te salvou a vida, mas ele" (SARAMAGO, 1991, p. 255).

São estes tipos de situações que fazem Cristo, em meio a sua existência conturbada, questionar o quanto este sagrado é benéfico. As imposições, feitas a partir de proibições e ameaças, deixam a personagem confusa. Além de não ser guiado pelo divino, há a sensação de perigo, uma opressão emocional e psicológica.

A obra literária passa uma noção de que Deus é um tirano, e o sagrado é um método usado como manipulação dessa força superior. Acatar aos desejos, por parte desse sagrado é, segundo Nietzsche, "uma violentação e uma crueldade contra a razão" (NIETZSCHE, 2009, p. 100), além de que o ideal desse Deus fora capaz de apoderar-se dos indivíduos, impondo uma "civilização e domesticação do homem" (NIETZSCHE, 2009, p. 101) com base na hostilidade e terror.

Portanto, o sagrado não passa a sensação de completude que deveria. Pelo contrário, estabelece-se uma relação de poder, na qual a submissão do homem é evidenciada. A obra portuguesa expressa o símbolo máximo desta categoria, Deus, como um ser que controla o mundo sem se importar com as consequências, pois tais se fazem sentir apenas nos mortais. Quando Cristo, em meio a suas andanças pelo mundo, chega a um deserto e encontra, em forma de uma voz que vem das nuvens, Deus, nota-se o quão sem valor é para o sagrado o homem, não sendo mais que uma peça que possui uma utilidade específica, para em seguida ser descartada:

Uma nuvem da altura de dois homens, que era como uma coluna de fumo girando lentamente sobre si mesma, estava diante dele, e a voz viera da nuvem. Quem me fala, perguntou Jesus, arrepiado, mas adivinhando já a resposta. A voz disse, Eu sou o Senhor [...]. Trouxesteme aqui, que queres de mim, perguntou, Por enquanto nada, mas um dia hei de querer tudo, Que é tudo, A vida [...] (SARAMAGO, 1991, p. 260261) 
O diálogo entre as personagens possibilita pensar que o sagrado apenas se aproxima do homem em momentos nos quais há algum ganho para si, ou seja, Deus conversa com Jesus com o intuito, além de se firmar como superior, de deixar explícito que ele possui uma utilidade e deve servi-lo. Tal situação mostra que, no contexto da narrativa, os indivíduos, mais do que repudiados pelo sagrado, possuem a atribuição de objetos para determinados fins.

A impressão que o primeiro encontro entre Jesus e Deus passa é a de inferioridade do primeiro em relação ao segundo, como uma habilidade desse divino de limitar, parecendo que a existência do mortal é apenas um processo de compreensão do "adestramento" que sofre por parte do sagrado. Aquilo que deveria preencher o vazio da vida das pessoas, como, por exemplo, o vazio que há em Jesus depois da morte de seu pai, na verdade intensifica as dores e as tristezas, resultando em um "desmoronamento" do sujeito, ou seja, uma falta de esperança em seu percurso na terra.

O sagrado, por vontade própria, não auxilia a humanidade, resultando que essa enxerga a vida como uma constante adversidade, acabando por se transformarem em "criaturas descontentes, arrogantes e repulsivas, que jamais se livram de um profundo desgosto de si, da terra, de toda a vida, e que a si mesmas infligem o máximo de dor possível” (NIETZSCHE, 2009, p. 99). Por se sentir sem esperanças, o sujeito se consome, destrói-se através de seus lamentos e sensação de desamparo.

Sem outras opções, a personagem Jesus caminha perdido, tentando encontrar um enfoque para a sua existência, como busca algo que o possibilite suportar o fardo de ser uma posse de Deus. A busca por resposta faz com que se torne um andarilho, visto por muitos como um mendigo. ${ }^{9}$ Caminhando incansavelmente, Cristo encontra uma pessoa que muda a sua vida, a personagem Maria Magdala. Uma prostituta com a qual se envolve e se apaixona. Usufruindo dos prazeres carnais, a personagem finalmente se sente livre.

Todavia, Jesus carrega em si duas questões que podem ser vistas como conflituosas. De um lado, há o seu lado humano, que ama e deseja Maria Magdala. De outro, transitam por sua mente as palavras de Deus, além das

\footnotetext{
${ }^{9} \mathrm{O}$ abandono de Deus faz com que uma personagem como Cristo se veja em uma condição precária, sem dinheiro e com vestes esfarrapadas, passando um "ar de vagabundo" (SARAMAGO, 1991, p. 270). Logo, a personagem demonstra estar deslocada, perdida em meio a multidão.
} 
informações que ele, Jesus, virá a possuir poder e glória, com a finalidade de servir à vontade do divino.

Jesus sintetiza os questionamentos acerca do sagrado, expostos no romance de Saramago, sendo ele a personificação de um sagrado imperfeito, 0 qual se sujeita a falhas, como a tentações. Em uma situação em que surge a sua frente um homem possuído por demônios, Cristo sente ter o poder necessário para libertá-lo, ainda mais quando este demônio, que se autodenomina "Legião", diz ser Jesus o filho de Deus: "Jesus, como quem acabasse de reconhecer-se noutro, sentiu-se, também ele, como que possesso, possesso de uns poderes que o levariam não sabia aonde ou a quê" (SARAMAGO, 1991, p. 352).

Atenta-se para a questão de que ao ter ciência dos poderes, como da grandeza que possui, Jesus toma atitudes distintas de anteriormente. $O$ sujeito simples, temente a Deus e que precisava de respostas para conduzir a sua existência se via, naquele contexto, como capacitado a salvar a alma de um outro. A ideia de que é sagrado gera em Cristo um sentimento de superioridade, como um ser detentor de habilidades divinas, as quais poderiam agora não só o conduzir, mas trazer maiores perspectivas.

Entretanto, mesmo conseguindo libertar o homem dos domínios de Legião, os espíritos dos demônios vão em direção a porcos, que se encontravam por perto, adentrando nos animais. Estes, dominados e confusos, jogam-se ao mar e começam a se afogar. Ao fundo, escutam-se apenas duas vozes, a dos donos dos porcos, criticando a ação de Jesus, e a de Legião desferindo gargalhadas. Observando a cena, de um Cristo sentindo que sua atitude fora, no mínimo, precipitada, as palavras antes ditas pelo narrador se mostram plausíveis para o ocorrido: "[...] a verdade é que nem mesmo um filho de Deus, aliás ainda não habituado a tão alto parentesco, poderia prever, como no xadrez, todas as consequências dum simples lance, duma decisão simples" (SARAMAGO, 1991, p. 353).

A possibilidade de alcançar poderes que advém do sagrado resulta em movimentos precipitados, do mesmo modo que gera uma postura prepotente na personagem. A desconstrução do sagrado também aborda a perspectiva de que esta força não apenas limita o indivíduo, mas também pode lhe passar a falsa sensação de magnitude. 
Fatores como a soberba e a arrogância brotam desse sagrado quando o indivíduo crê, como no caso do Cristo saramaguiano, ter um vínculo poderoso com o divino. No livro $O$ anticristo (1895), Nietzsche apresenta a perspectiva de que há nos seguidores de Deus e, por consequência, da religião, o intuito de superar as limitações, como de engrandecer e manifestar as intenções que carregam em si naquilo que é considerado sagrado:

Ao fazer com que Deus julgue, eles mesmos julgam; ao glorificar a Deus, glorificam a si mesmos; enquanto exigem precisamente as virtudes de que são capazes - mais ainda, de que necessitam para permanecer no topo -, dão a si mesmos a grande impressão de uma luta pela virtude. "Nós vivemos, morremos, nos sacrificamos pelo bem" [...] (NIETZSCHE, 2012, p. 81)

Ao surgir alguma oportunidade, a humanidade tenta se divinizar, atribuir os valores do sagrado para a realidade mundana. Porém, na ficção é possível perceber que os seres sagrados, por excelência, na verdade são tão sujeitos a tentações como seus seguidores. Desconstrói-se a ideia de sagrado no momento em que algo como Deus tem uma postura próxima dos sujeitos que o veneram, abusando do poder que tem e somente se importando com que acha correto, com suas intenções. ${ }^{10}$

Percebendo o erro que cometeu, Cristo questiona tanto a Deus quanto a si mesmo, colocando uma vez mais em dúvida a suposta perfeição divina: "Escuta-me, ó Senhor, ou tu escolheste mal o filho que disseram que eu sou e háde cumprir os teus desígnios, ou entre os teus mil poderes falta o duma inteligência capaz de vencer a do diabo" (SARAMAGO, 1991, p. 354-355). A sabedoria divina é posta em suspeita, Deus aparenta não possuir a sapiência que Ihe atribuem. Pelo contrário, a figura sagrada parece conturbar a realidade do mundo. A opinião de Nietzsche, exposta logo a seguir, exemplifica tal ponto: "O velho Deus [...] separa os povos, faz com que os homens se aniquilem mutuamente" (NIETZSCHE, 2012, p. 91).

Posteriormente, Jesus se encontra novamente com Deus. Em diálogo no qual está presente Pastor, que se revela como o próprio Diabo, Deus começa a

\footnotetext{
${ }^{10}$ Sintetizando tal raciocínio, o sagrado é, de certo modo, desvalorizado a partir do momento em que não se nota mais superioridade, distanciamento quanto a diferença de características. Pelo contrário, o romance deixa claro uma aproximação do divino e do mortal, como questões de considerável instabilidade.
} 
explicar sobre os planos que possui para o seu filho, deixando claro como pretende usá-lo para adquirir uma "maior influência" sobre a humanidade:

Se cumprires bem o teu papel, isto é, o papel que te reservei no meu plano, estou certíssimo de que em pouco mais de meia dúzia de séculos, embora tendo de lutar, eu e tu, com muitas contrariedades, passarei de deus dos hebreus a deus dos que chamaremos católicos, à grega, E qual foi o papel que me destinaste no teu plano, $O$ de mártir, meu filho, o de vítima, que é o que melhor há para fazer espalhar uma crença e afervorar uma fé. (SARAMAGO, 1991, p. 368)

Atordoado pela fala de Deus, Cristo se sente realmente manipulado, percebendo o quanto é de pouco valor a sua vida para o sagrado. O calafrio que o percorre ao escutar as expressões mártir e vítima faz com que veja como o divino pode ser pérfido, cruel com o homem.

Jesus observa que Deus pretende apenas obter mais poder, independentemente de quais artifícios sejam necessários para tal. Tentando discordar da palavra do Senhor, a personagem escuta que esta é a utilidade do ser humano, a de servir, e que Deus não mede ações porque "Deus é Deus, não tem remorsos" (SARAMAGO, 1991, p. 388).

Desse modo, a personagem tem a ciência de que não pode se opor, pois ele se trata de uma peça nos planos do sagrado. Não há proteção deste para com o indivíduo, tal categoria não traz serenidade, apenas torna seus seguidores escravos de um senhor que, como todo o detentor de poder, deseja obter mais e explorar seus recursos, ou seja, a humanidade, com a finalidade de ampliar a própria capacidade de reinar.

Ademais, Deus afirma que no executar de seu plano muito sangue será derramado, desespero e morte serão questões necessárias no desenvolver dessas intenções. O diabo, em silêncio, mas atento a cada ponto da conversa, diz que "É preciso ser-se Deus para gostar de tanto sangue" (SARAMAGO, 1991, 389). Cria-se, na ficção, um cenário que demonstra, mais que uma proximidade, semelhança entre o que deveria ser sagrado e o que é diabólico. O sagrado violenta, fere e destroça o homem, motiva chacinas, as quais o devoto apenas se submete.

Depois das colocações de Deus, Jesus compreende o quanto está destinado a sucumbir devido ao sagrado. Fadado a sofrer, a possibilidade de amenizar o seu desespero seria o divino, a energia superior. Todavia, é por causa 
desse sagrado que o seu futuro surge para si tendo como possibilidade a dor, uma morte agoniante como um sacrifício. Em Origem do drama barroco alemão, Walter Benjamin expõe a ideia de destino envolvida pela culpa e pela agonia, quando o sujeito assume o papel de herói ou de mártir: "O destino conduz à morte. Ela não é castigo, mas expiação, uma sujeição da vida culpada à lei da vida natural. A culpa [...] está em seu elemento no destino e no drama de destino" (BENJAMIN, 1984 , p. 154).

Seguindo a linha de raciocínio benjaminiana, Jesus é culpado, de certa maneira, pois se deixa conduzir pelos dogmas divinos, do mesmo modo que a sua culpa significa responsabilidade, uma responsabilidade atribuída a si pelo o que há de mais sagrado, Deus. Atenta-se que o contexto no qual a personagem está inserida é de uma existência precária, de dificuldade, em que os indivíduos encontram como "fonte" de amor e sabedoria o sagrado, sintetizando, Deus.

A problemática se encontra na questão de que esse sagrado é o que gera o terror no mundo. Devido a seus posicionamentos, o homem passa por constantes provações que o desgasta, e que servem unicamente para enfatizar o "cargo" de dominador que o divino exerce. Tudo que ocorre, tanto no sentido bom quanto ruim, tem por trás de si os movimentos do ser dito como superior.

Devido ao encontro com Deus, Cristo nota como a vida do homem é efêmera, pequena, insignificante. $\mathrm{O}$ destino de cada um, do rico ao pobre, está nas mãos do sagrado, e expressa um sentido simples, que é o nada, uma sensação de vazio. Como apresenta Benjamin, há "uma crença sombria na sujeição do homem ao destino. As ações humanas foram privadas de todo valor. Algo de novo surgiu: um mundo vazio" (BENJAMIN, 1984, p. 162), este valor que foi privado, no caso da narrativa, é o valor essencialmente humano, individual, pois por trás dos atos do sujeito, que obedece como uma marionete, estão as ordens do sagrado.

Percebendo que de nada adiantaria discordar de Deus, Jesus decide encerrar o assunto. Quando ia se retirar, viu o diabo se aproximar de Deus, e fazer uma proposta curiosa, a de aceitá-lo uma vez mais no céu, para assim terminar com o mal na terra. Porém, Deus nega tal pedido por afirmar que sem ele (o diabo), não poderia realmente ser Deus: 
Não te aceito, não te perdoo, quero-te como és, e, se possível, ainda pior do que és agora, [...] Porque este Bem que eu sou não existiria sem esse Mal que tu és, [...] enfim, se tu acabas, eu acabo, para que eu seja o Bem, é necessário que continues a ser o Mal, se o Diabo não vive como Diabo, Deus não vive como Deus, a morte de um seria a morte do outro (SARAMAGO, 1991, p. 390-391)

A desconstrução do sagrado, como mesmo a descrença por parte de Jesus, alcança o ponto mais alto nesse momento na narrativa. Deus permite a existência dos males com a finalidade de se manter Deus, o objetivo maior é persistir como a imagem do "Bom", mesmo que isso signifique que o homem deva sofrer com as artimanhas de um diabo que somente exerce um papel designado a ele por aquilo que se diz divino. O sentimento de incompletude que antes já consumia Jesus, agora é realçado pelo nítido desdém dos céus para com aquele, como para com o resto do mundo.

Cristo se torna, então, usufruindo-se das colocações de Giorgio Agamben (1942) em O homem sem conteúdo (2013), um "homem que [...] não consegue mais reencontrar a si mesmo na história" (AGAMBEN, 2012, p. 175). O sujeito, a partir da situação de perda da ideia que servia como base para a sua vida, como para suportá-la, encontra-se sem rumo, deslocado e, ressaltando uma vez mais, vazio. O sagrado é o fator que gera a sensação de vazio e de descrença, existir se mostra como interminável amargura.

A personagem perde a devoção, desconstrói a imagem do divino, vendo que esse Deus é o principal responsável pela sua queda e a de tantos homens. Em seus últimos instantes de vida, quando está no momento da crucificação em meio a tanta dor, Cristo exclama, com tristeza: "Homens, perdoai-Ihe, porque ele (Deus) não sabe o que fez" (SARAMAGO, 1991, p. 442). O desespero de Cristo sintetiza a desconstrução do sagrado por parte do livro de Saramago, Deus comete erros e os desconta no homem, sendo a razão para a atmosfera de agonia que há na ficção. Em suma, o sagrado se mostra não como a salvação, mas a queda do homem.

\section{REFERÊNCIAS:}

AGAMBEN, Giorgio. O homem sem conteúdo. Belo Horizonte: Autêntica, 2012.

BENJAMIN, Walter. Origem do drama barroco alemão. São Paulo: Brasiliense, 1984. 
FREUD, Sigmund. Psicologia das massas e análise do eu. Porto Alegre: L\&PM, 2013.

NIETZSCHE, Friedrich. Humano, demasiado humano. São Paulo: Companhia das Letras, 2005.

NIETZSCHE, Friedrich. Genealogia da moral. São Paulo: Companhia das Letras, 2009.

NIETZSCHE, Friedrich. O Anticristo. Porto Alegre: L\&PM, 2012.

SARAMAGO, José. O evangelho segundo Jesus Cristo. São Paulo: Companhia das Letras, 1991.

SCHOPENHAUER, Arthur. Aforismos para a sabedoria de vida. Porto Alegre: L\&PM, 2014.

SCHOPENHAUER, Arthur. As dores do mundo. São Paulo: EDIPRO, 2014.

Data da Submissão: 30/04/2018

Data da Aprovação: 26/07/2018 